\title{
BIOADSORPSI Pb(II) MENGGUNAKAN KULIT JERUK SIAM (Citrus reticulata)
}

\section{Bioadsorptsion of $\mathrm{Pb}(\mathrm{II})$ using Tangerine Peel (Citrus reticulata)}

\author{
*Nafikatus Solika, Mery Napitupulu, dan Siang Tandi Gonggo
}

Pendidikan Kimia/FKIP - Universitas Tadulako, Palu - Indonesia 94118

Received 05 Juni 2017, Revised 07 Juli 2017, Accepted 07 Agustus 2017

doi: 10.22487/j24775185.2017.v6.i1.xxxx

\begin{abstract}
A research about the bioadsorption of $\mathrm{Pb}(\mathrm{II})$ using tangerine peel (Citrus reticulata) has been done. The purpose of this study is to determine the optimum contact time of tangerine peel and to determine the $p H$ of the tangerine peel on the adsorption power of $\mathrm{Pb}(\mathrm{II})$ in solution. The method used in this study was a laboratory experiment using the tangerine peel waste as the adsorbent of $\mathrm{Pb}(\mathrm{II})$. The concentration of $\mathrm{Pb}(I I)$ adsorbed was measured using a spectrophotometer spectrodirect. The results showed that the optimum contact time of adsorption the metal ions Pb(II) was 60 minutes with the absorption efficiency of $96.19 \%$. The $p H$ optimum of adsorption of the metal ion Pb(II) was at $\mathrm{pH} 4.0$ with the absorption efficiency of $93.05 \%$.
\end{abstract}

Keywords: Tangerine peel, adsorption, $\mathrm{Pb}(\mathrm{II})$, spectrodirect, $\mathrm{pH}$ variation.

\section{Pendahuluan}

Banyaknya limbah dari industri pengguna logam berat atau bahan yang mengandung logam berat dapat meningkatkan pencemaran logam berat pada udara, tanah atau daratan dan air. Pencemaran lingkungan oleh pembuangan air limbah industri ke perairan tanpa dilakukan pengolahan terlebih dahulu dapat menyebabkan pencemaran air. Air bersih merupakan salah satu kebutuhan utama mahkluk hidup. Sumber air menjadi suatu hal yang penting dan harus dijaga keberadaannya. Namun seiring dengan perkembangan jaman, proses industrialisasi menjadi tak terelakkan. Salah satu dampak proses industrialisasi adalah peningkatan volume limbah yang dapat mencemari perairan. Sumber utama pencemaran air di antaranya adalah logam berat. Industri elektroplanting, logam penyamakan kulit, pupuk, pembuatan baterai serta pembuatan pigmen banyak menghasilkan limbah berupa logam berat (Igwe \& Abia, 2006).

Bidang industri di Indonesia pada saat ini berkembang cukup pesat. Perkembangan dunia industri banyak memberikan dampak terhadap kehidupan manusia baik yang positif maupun negatif. Dampak negatif yang dihasilkan adalah peningkatan konsentrasi bahan-bahan pencemar yang mengganggu lingkungan. Hal ini dapat dilihat dengan semakin banyaknya industri yang memproduksi berbagai jenis kebutuhan manusia seperti industri kertas, tekstil, dan penyamakan kilit, dengan adanya pertambahan industri tersebut, maka semakin banyak pula hasil sampingan dan limbah yang akan mencemari lingkungan sekitar, salah satunya adalah logam berat, limbah logam berat merupakan limbah yang bersifat racun dan berbahaya. Beberapa logam berat yang

${ }^{*}$ Correspondence

Nafikatus Solika

Program Studi Pendidikan Kimia, Fakultas Keguruan dan IImu Pendidikan, Universitas Tadulako

e-mail: nafikatussolika99@gmail.com

Published by Universitas Tadulako 2017 dapat mencemari lingkungan dan bersifat toksik adalah krom (Cr), perak (Ag), cadmium (Cd), timbale $(\mathrm{Pb})$, zinl $(\mathrm{Zn})$, merkuri $(\mathrm{Hg})$, tembaga $(\mathrm{Cu})$, besi $(\mathrm{Fe})$, molibdat $(\mathrm{Mo})$, nikel $(\mathrm{Ni})$, timah $(\mathrm{Sn})$, kobal (Co) dan unsur-unsur logam ringan seperti arsen, aluminium (Al), dan selenium (Purwaningsih, 2009).

Pada umumnya semua logam berat tersebar di seluruh permukaan bumi tanah, air maupun udara. Beberapa diantaranya berperan penting dalam kehidupan makhluk hidup dan disebut sebagai hara mikro esensial. Logam berat umumnya bersifat racun terhadap makhluk hidup, walaupun beberapa diantaranya diperlukan dalam jumlah kecil. Melalui berbagai perantara, seperti udara, makanan, maupun air yang terkontaminasi oleh logam berat, logam tersebut dapat terdistribusi kebagian tubuh manusia dan sebagian terakumulasikan. Jika keadaan ini berlangsung terus-menerus, dalam jangka waktu lama dapat mencapai jumlah yang membahayakan kesehatan manusia (Diantarani, 2006).

Berbagai alternatif bahan-bahan biologis dapat digunakan sebagai bahan baku biosorben adalah limbah produk-produk pertanian. Limbah produk pertanian merupakan limbah organik yang sangat mudah ditemukan dalam jumlah besar. Pemanfaatan dan penggunaan limbah pertanian sebagai bahan baku biosorben selain dapat membantu mengurangi volume limbah juga dapat memberdayakan limbah menjadi suatu produk yang mempunyai nilai jual. Oleh karena itu, potensi limbah pertanian cukup besar untuk digunakan sebagai bahan baku biosorben logam berat (Kurniasari, 2010). Berbagai limbah pertanian yang dapat dimanfaatkan sebagai bahan baku biosorben diantaranya adalah jerami padi, kulit jeruk siam, kulit kentang, kulit buah-buahanserta daun dan ranting tanaman-tanaman tertentu.

Komponen yang berperan dalam proses adsorpsi logam berat dengan adsorben bahan-bahan biologis adalah keberadaan gugus aktif yang ada di bahan tersebut. Gugus-gugus itu diantaranya adalah 
acetamido pada kitin, gugus amino dan posphat pada asam nukleat, gugus amido, amino, sulphydryl dan karboksil pada protein dan gugus hidroksil pada polisakarida. Gugus-gugus itulah yang akan menarik dan mengikat logam pada biomassa (Ahalya, dkk., 2003).

Pektin merupakan salah satu senyawa yang terdapat pada dinding sel tumbuhan daratan. Pektin merupakan polimer dari asam D-galakturonat yang dihubungkan oleh ikatan 1,4 glikosidik dan banyak terdapat pada lamella tengah dinding sel tumbuhan. Selama ini pektin banyak dimanfaatkan dalam industri makanan, farmasi, dan kosmetik. Industriindustri tersebut pektin digunakan terutama sebagai bahan pembentuk gel. Namun bila mengingat bahwa struktur komponen pektin juga banyak mengandung gugus aktif, maka pektin juga dapat digunakan sebagai salah satu sumber biosorben (Wong, dkk., 2008).

Salah satu buah-buahan yang mengandung pektin adalah keluarga jeruk, jeruk siam (Citrus reticulata) banyak diminati oleh masyrakat karena rasanya manis tanpa diberi penambahan gula, dan jeruk siam adalah jeruk yang sekitar 30\% bagian buahnya berupa kulit yang selama ini tidak dipergunakan serta dibuang begitu saja sehingga menjadi sampah. Pektin dari kulit jeruk siam termaksud pektin bermetoksil rendah, sehingga potensi digunakan sebagai bioadsorpsi (Ina, 2014). Berdasarkan kadar metoksilnya, pektin dibedakan atas dua macam, yaitu pektin bermetoksil tinggi yang mengandung 7-12 meter ester dan pektin bermetoksil rendah dengan kandungan 3-7 meter ester. Pektin yang mempunyai kadar metoksil tinggi larut dalam air, sedangkan pektin berkadar metoksil rendah larut dalam alkali dan asam oksalat (Fitriani, 2003).

\section{Metode}

Alat utama yang digunakan yaitu Spektrofotometer SpektroDirect (Lovibond) dan oven. Sedangkan untuk bahan yang digunakan yaitu Kulit jeruk siam, aquades, kertas saring, Kristal $\mathrm{Pb}\left(\mathrm{NO}_{3}\right)_{2}$ (Merck), $\mathrm{HNO}_{3}$ (Merck), dan $\mathrm{NaOH}$ (Merck).

\section{Prosedur kerja}

Kulit jeruk siam dicuci dengan air mengalir, lalu kulit jeruk dipotong kecil-kecil dan dikeringkan di bawah sinar matahari. Kemudian sampel dihaluskan menggunakan blender dan diayak dengan ayakan 100 mesh. 4 gram serbuk kulit jeruk siam ditempatkan dalam cawan porselin kemudian dikeringkan dalam oven pada suhu $105^{\circ} \mathrm{C}$ selama 3 jam. Selanjutnya sampel didinginkan dalam eksikator lalu ditimbang. Pengeringan dilakukan beberapa kali sampai diperoleh bobot yang tetap. Penentuan dilakukan tiga kali pengulangan.

\section{Pengaruh waktu sentuh kulit jeruk siam}

$1 \mathrm{~g}$ adsorben dimasukkan dalam $50 \mathrm{~mL}$ larutan $\mathrm{Pb}$ (II) 100 ppm dengan menambahkan 5-10 tetes $\mathrm{NaOH} 0,1 \mathrm{~N}$ dan ditambahkan 1 tetes $\mathrm{HNO}_{3}$ $0,1 \mathrm{~N}$ kemudian dimasukkan dalam tabung Erlenmeyer $100 \mathrm{~mL}$. Selanjutnya masing-masing tabung Erlenmeyer tersebut ditutup aluminium foil dan dikocok menggunakan shaker kemudian didiamkan selama 24 jam. Dengan variasi waktu 60, 90, 120, 150, dan 180 menit. Selanjutnya, filtrat dipisahkan dengan penyaringan menggunakan kertas saring. Kemudian, mengukur adsorbansi larutan dengan menggunakan spektrofotometer spektro-direct.

\section{Pengaruh $p H$ terhadap adsorpsi $\mathrm{Pb}(\mathrm{II})$}

Sebanyak $60 \mathrm{~mL}$ larutan $\mathrm{Pb}(\mathrm{II}) \quad \mathrm{ppm}$ dimasukkan ke dalam 5 buah Erlenmeyer yang berbeda. Lalu menambahkan larutan buffer yang telah dibuat dengan $\mathrm{pH} 3,0 ; 4,0 ; 5,0 ; 6,0 ;$ dan7,0 ke dalam labu Erlenmeyer. Masing-masing larutan $\mathrm{Pb}$ dicampur dengan 0,5 gram adsorben dalam labu Erlenmeyer. Selanjutnya Erlenmeyer ditutup dengan kertas aluminium foil diikat dengan karet dan dikocok dengan shaker selama 20 menit kemudian mendiamkannya selama 24 jam. Memisahkan filtrat dan residu dengan menggunakan kertas saring. Kemudian mengukur konsentrasi larutan dengan mengguanakan spektrofotometer spektro-direct.

Analisis presentase adsorpsi (efisiensi adsorpsi) dalam penelitian ini digunakan persamaan : $\mathrm{C}_{\mathrm{b}}=$ $\mathrm{C}_{\mathrm{i}}-\mathrm{C}_{\mathrm{eq}} \quad$ dan $\% \mathrm{Cr}=\frac{\mathrm{C}_{\mathrm{b}}}{\mathrm{C}_{\mathrm{i}}} \times 100 \%$; dimana: $\mathrm{C}_{\mathrm{b}}$ adalah konsentrasi $\mathrm{Cr}$ yang terjerap $(\mathrm{mg} / \mathrm{L}) ; \mathrm{C}_{\mathrm{i}}$ adalah konsentrasi awal larutan $(\mathrm{mg} / \mathrm{L}) ; \mathrm{C}_{\mathrm{eq}}$ adalah konsentrasi akhir larutan (mg/L) (Atkins, 1999).

\section{Hasil dan Pembahasan}

Sesuai dengan pernyataan Oscik \& Cooper (1982), bahwa efisiensi adsorpsi merupakan fungsi luas permukaan adsorben. Semakin besar luas permukaan adsorben semakin besar pula kapasitas suatu adsorben dalam mengadsorpsi suatu adsorbat. Konsentrasi slogam timbal dalam keadaan kesetimbangan diketahui dengan menggunakan SpectroDirect. Jumlah logam timbal terserap $\left(\mathrm{C}_{\mathrm{b}}\right)$ oleh biosorben kulit jeruk siam adalah selisih konsentrasi timbal mula-mula $(\mathrm{Ci})$ dengan konsentrasi timbal pada saat kesetimbangan $\left(\mathrm{C}_{\mathrm{eq}}\right)$.

\section{Variasi waktu kontak biosorben terhadap adsorpsi ion logam timbal(II)}

Waktu kontak merupakan salah satu faktor yang mempengaruhi proses adsorpsi, karena melalui proses kontak penyerapan terjadi sebagai akibat dari interaksi fisik (adhesi) antara adsorbat dengan adsorben. Penentuan waktu kontak optimum pada adsorpi ion timbal menggunakan adsorben kulit jeruk siam dilakukan pada variasi waktu $60,90,120,150$, dan 180 menit. Penentuan waktu optimum bertujuan 
untuk mengetahui waktu kontak optimum dari adsorpsi larutan ion logam timbal oleh adsorben kulit jeruk siam dapat dilihat pada Gambar 1.

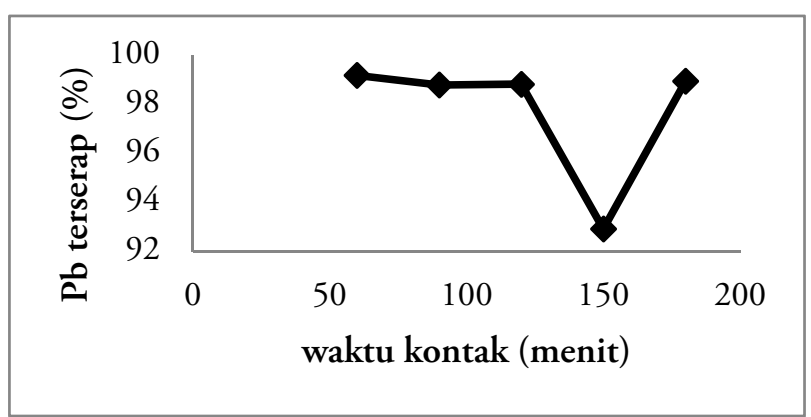

Gambar 1. Kurva hubungan antara waktu sentuh (menit) terhadap persen ion $\mathrm{Pb}$ terserap

Hasil penelitian untuk pengaruh waktu kontak dari larutan ion logam timbal terhadap kemampuan adsorpsi biosorben kulit jeruk siam seperti yang terlihat pada Gambar 1 yang memperlihatkan bahwa adsorpsi $\mathrm{Pb}$ dipengaruhi oleh waktu kontak antara larutan dan sampel biosorben. Gambar 1 menunjukkan bahwa waktu kontak yang paling optimum yang diperoleh adalah pada waktu menit ke-60. Persentasi penyerapan ion timbal oleh biosorben kulit jeruk siam pada masing-masing variasi waktu adalah pada 60 menit sebesar 99,18\%, 90 menit sebesar 98,79\%, pada 120 menit sebesar $98,82 \%$, pada 150 menit sebesar $98,93 \%$, dan pada 180 menit sebesar $98,95 \%$.

Menit waktu ke-60 kemampuan adsorben kulit jeruk siam dalam mengadsorpsi timbal terjadi penyerapan yang sangat tinggi. Sedangkan selanjutnya serapan timbal menurun pada waktu 90 sampai 150 menit yang kemudian meningkat kembali pada waktu 180 menit.

Hasil yang diperoleh dapat dijelaskan bahwa, pada menit awal serapan timbal meningkat karena interaksi antara ion logam dan adsorben terjadi secara efektif. Hal ini disebabkan karena semua sisi aktif yang terdapat pada biosorben kulit jeruk saling berikatan dengan ion-ion timbal dalam larutannya. Proses penyerapan ini berlangsung sangat cepat karena proses penyerapan ion logam oleh adsoben tidak melibatkan proses metabolisme (Nurdin, 1998).

Waktu kontak antara ion logam dengan adsorben sangat mempengaruhi daya serap. Semakin lama waktu kontak maka penyerapan juga akan meningkat sampai pada waktu tertentu akan mencapai maksimum dan setelah itu akan turun kembali dan kemudian akan meningkat kembali. Pada penelitian ini, waktu kontak optimum diperoleh pada menit ke -60 dengan penyerapan mencapai 99,18\%. Hal ini terjadi karena ion-ion timbal yang terdapat di dalam larutan telah teradsorpsi sepenuhnya oleh biosorben, dengan kata lain ion-ion timbal pada larutan telah habis teradsorpsi oleh biosorben. Selain itu, hal tersebut juga dapat terjadi karena permukaan biosorben sudah dalam keadaan jenuh dengan ion-ion logam timbal sehingga peningkatan berat biosorben relatif tidak lagi mempengaruhi peningkatan ion logam oleh biosorben (Radyawati, 2011).

Efisiensi penyerapan menurun setelah menit ke60 , diduga terjadi proses kesetimbangan atau terjadi tingkat kejenuhan antara fase molekul terlarut dengan material organik terhadap waktu kontak. Artinya ketika hampir semua sisi aktif pada adsorben telah bereaksi dengan ion logam maka perpanjangan waktu kontak relatif tidak lagi meningkatkan jumlah ion $\mathrm{Pb}$ (II) yang terserap pada Kulit jeruk siam. Hal ini merupakan fenomena dalam adsorpsi fisika yang menyatakan bahwa proses adsorpsi bersifat reversibel (Sukardjo, 1990). Hal ini karena, ikatan lemah yang terjadi antara adsorben dengan ion logam akan lepas kembali ke dalam larutannya karena semakin lama waktu kontak (Lestari, 2010).

Data tersebut menunjukkan persentase penyerapan jumlah timbal yang paling optimum yang diperoleh dalam proses waktu kontak adalah pada waktu 60 menit. Waktu kontak tersebut merupakan waktu kontak optimum, dimana terjadi penurunan kadar timbal dalam sampel telah mencapai titik maksimalnya, maka akan digunakan untuk keperluan variabel penelitian selanjutnya, agar data yang diperoleh menggambarkan efektivitas serapan adsorben yang optimum (Radyawati, 2011).

\section{Variasi $p H$ biosorben terhadap adsorpsi ion timbal}

Derajat keasaman $(\mathrm{pH})$ merupakan faktor yang sangat mempengaruhi proses adsorpsi ion logam dalam larutan, karena keberadaan ion $\mathrm{H}^{+}$dalam larutan akan berkompetisi dengan kation untuk berikatan dengan situs aktif. Selain itu, $\mathrm{pH}$ juga akan mempengaruhi spesies ion yang ada dalam larutan sehingga akan mempengaruhi terjadinya interaksi ion dengan situs aktif adsorben (Lestari, dkk., 2003). Penentuan $\mathrm{pH}$ optimum pada adsorpsi ion timbal menggunakan biosorben kulit jeruk siam dilakukan pada variasi $\mathrm{pH} 3,0 ; 4,0 ; 5,0 ; 6,0$ dan 7,0. Gambar 2 penentuan $\mathrm{pH}$ optimum ini bertujuan untuk mengetahui $\mathrm{pH}$ optimum dari adsorpsi larutan ion timbal oleh biosorben.

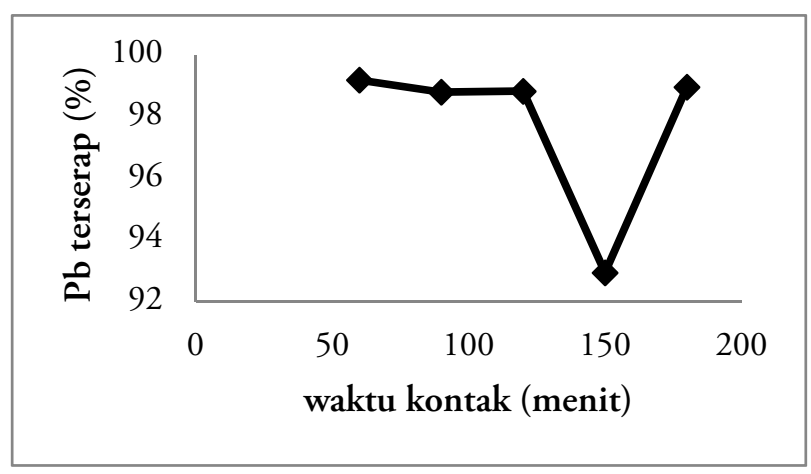

Gambar 2. Kurva hubungan antara $\mathrm{pH}$ terhadap persen ion $\mathrm{Pb}$ terserap

Berdasarkan Gambar 2 terlihat bahwa proses adsorpsi mengalami peningkatan seiring dengan meningkatnya $\mathrm{pH}$, tetapi mengalami penurunan setelah melewati titik optimum yang dicapai. Dimana 
$\mathrm{pH}$ 3,0 sampai 4,0 adsorpsi ion timbal mengalami peningkatan yaitu dengan persentasi masing-masing sebesar $97,08 \%$ dan $97,48 \%$, sedangkan pada $\mathrm{pH}$ 5,$0 ; 6,0 ;$ dan 7,0 adsorpsi ion timbal persentasi serapannya menurun yaitu masing-masing sebesar 95,10\%, 95,03\%, dan 93,98\%.

Rendahnya penyerapan yang terjadi pada $\mathrm{pH} 5,0$; 6,0; dan 7,0 ini disebabkan karena adanya beberapa kemungkinan yaitu pertama, karena pada $\mathrm{pH}$ rendah terjadi persaingan antara $\mathrm{H}^{+}$dengan $\mathrm{Pb}^{2+}$ untuk berinteraksi dengan gugus fungsional yang ada pada permukaan biosorben kulit jeruk siam; kedua, pada $\mathrm{pH}$ rendah gugus fungsional yang ada pada permukaan biosorben kulit jeruk siam dikelilingi oleh ion $\mathrm{H}^{+}$sehingga mencegah terjadinya interaksi antara ion timbal dengan gugus fungsi pada permukaan biosorben kulit jeruk siam (Tumin, dkk., 2008), dan ketiga, permukaan biosorben kulit jeruk siam bermuatan positif sehingga terjadi penolakan secara elektrostatik terhadap ion $\mathrm{Pb}^{2+}$ (Sharma, dkk., 2009). Sedangkan pada $\mathrm{pH} 4$ adsorpsi yang terjadi sangat besar yaitu 97,48\% hal ini disebabkan karena jumlah ion $\mathrm{H}^{+}$berkurang sehingga dengan $\mathrm{H}^{+}$berkurang dan permukaan biosorben kulit jeruk siam cenderung terionisasi dengan melepas ion $\mathrm{H}^{+}$dan permukaan biosorben kulit jeruk siam menjadi negative (Vasu, 2008), sehingga terjadi interaksi elektrostatik antara permukaan biosorben kulit jeruk siam dengan ion $\mathrm{Pb}^{2+}$.

Ion timbal yang diserap pada $\mathrm{pH} 5-7$ menurun. Penurunan tersebut terjadi karena $\mathrm{pH}$ tinggi ion timbal mengalami hidrolisis menjadi ion bermuatan $\mathrm{Pb}^{+1}$ (Wirawan \& Lestari, 2008). Dengan terhidrolisisnya timbal maka muatan positifnya berkurang menjadi +1 sehingga interaksinya dengan permukaan biosorben kulit jeruk siam berkurang.

Penjerapan pada semua ion logam pada $\mathrm{pH}$ yang rendah dikarenakan, pada $\mathrm{pH}$ rendah permukaan adsorben dikelilingi oleh ion $\mathrm{H}^{+}$(karena gugus fungsi yang terdapat pada adsorben terprotonasi). Dalam kondisi asam permukaan adsorben juga bermuatan positif, yang akan menyebabkan terjadi penolakan antara adsorben dengan ion logam, sehingga adsorpsinya pun menjadi rendah (Sembiring, dkk., 2009)

Efisiensi penjerapan pada $\mathrm{pH}$ netral juga menurun. Hal ini disebabkan karena pada $\mathrm{pH}$ netral ion-ion logam dapat mengalami reaksi hidrolisis dalam larutan sehingga ia tidak stabil dalam bentuk ion logam semula dan menyebabkan kemampuan biosorben kulit jeruk siam untuk menyerapnya menurun. Sedangkan pada $\mathrm{pH}$ basa, ion-ion logam dapat membentuk endapan hidroksida sehingga efesiensi penyerapannya sukar untuk (Refilda, dkk., 2001)

\section{Kesimpulan}

Waktu sentuh optimum yang diperlukan biosorben kulit jeruk siam untuk menyerap timbal adalah pada waktu 60 menit dengan persentasi serapan 99,18\% kapasitas serapan sebesar 4,959 $\mathrm{mg} / \mathrm{g}$. Kondisi optimum untuk timbal diperoleh pada $\mathrm{pH}$ 4,0 dengan persentasi serapan 97,48\% kapasitas serapan sebesar $4,947 \mathrm{mg} / \mathrm{g}$.

\section{Ucapan Terima Kasih}

Penulis mengucapkan terima kasih yang sebesarbesarnya pada pihak yang telah membantu dalam melakukan penelitian ini, khususnya kepada Johanis Panggeso kepala Laboratorium Agroteknologi Fakultas Pertanian Universitas Tadulako serta Idha Kesuma Utami laboran Laboratorium Agroteknologi Fakultas Pertanian Universitas Tadulako yang telah serta kepada Tasrik laboran Laboratorium FKIP Universitas Tadulako.

\section{Referensi}

Ahalya, N., Ramachandra, T. V. \& Kanamadi, R. (2003). Biosorption of heavy metal Reserch Journal Chemical and Environment, 7(4), 71-79.

Atkins, P. W. (1999). Kimia fisik 2. Jakarta: Erlangga.

Diantarani, N. (2006). Penentuan kandungan logam $\mathrm{pb}$ dan cr pada air sedimen di sungai ao desa samsam kabupaten tabanan. Universitas Tabanan, Tidak diterbitkan.

Fitriani, V. (2003). Ekstrasi dan karakterisasi pektin dari kulit jeruk siam lemon (citrus medica var lemon). Bogor: Fakultas Teknologi Pertanian, IPB.

Igwe, J. \& Abia, A. (2006). A bioseparation processor removing heavy metals from water using biosorbents. African Journal of Biotechnology, 5(12), 1167-1179.

Ina, T. A. (2014). Pemanfaatan pektin kulit buah jeruk siam (citrus nobilis var. microcarpa) sebagai adsorben logam tembaga $(\mathrm{Cu})$. Yogyakarta: Universitas Atma Jaya.

Kurniasari, L. (2010). Pemanfaatan mikroorganisme dan limbah pertanian sebagai bahan baku biosorben logam berat. Majalah Ilmiah Momentum, 6(2), 5-8.

Lestari. (2010). Pengaruh berat waktu kontak untuk adsorpsi timbal(II) oleh adsorben dari kulit batang jambu biji (psidium guajaval). Jurnal Kimia Mulawarman, 8(1), 7-10.

Lestari, Eko, S. \& Mudair. (2003). Studi kemampuan adsorpsi biomassa saccharomyces cerevisiae yang termobilkan pada silika gel terhadap tembaga(II). Teknosains, 16A(3), 357-371.

Oscik, J. \& Cooper, L. (1982). Adsorption. New York: Ellis Horwood Limited

Purwaningsih, D. (2009). Adsorpsi multi logam $\mathrm{Ag}(\mathrm{I}), \mathrm{Pb}(\mathrm{II}), \mathrm{Cr}(\mathrm{III}), \mathrm{Cu}(\mathrm{II}), \mathrm{Ni}(\mathrm{II})$ pada silica dari abu sekam padi. Jurnal Penelitian Saintek, 14(1), 59-76. 
Rahman, N. (1998). Biosorpsi seng(II) dan kromium oleh biomassa aspergillus niger. Skripsi. Yogyakarta: Universitas Gajah Mada.

Radyawati. (2011). Pembuatan biocharcoal dari kulit pisang kepok untuk penyerapan logam timbal (pb) dan logam seng(zn). Palu: UniversitasTadulako.

Refilda, Rahmiana, Z. \& Rahmayeni. (2001). Pemanfaatan ampas tebu sebagai bahan alternatif pengganti penyerap sinttik logam-logam berat pada air limbah. Padang: Universitas Andalas.

Sembiring, Zipora, Buhani, Suharso \& Sumadi. (2009). Isoterm adsorpsi ion $\mathrm{Pb}(\mathrm{II}), \mathrm{Cu}(\mathrm{II})$, dan Cd(II) pada biomassa nannochloropsis, sp yang dienkapsulasi akuagel silika. Indonesian Journal of Chemistry, 9(1), 1-5.

Sharma, Y. C., Uma \& Upadhyay, S. N. (2009). Removal of a cationic dye from wastewater by adsorption on activated carbon developed from coconut coir. Energy and Fuels, 23, 2983-2988.
Sukardjo. (1990). Kimia anorganik. Jakarta: Rineka Cipta.

Tumin, N. D., Chuah, A. L. \& Rashid, S. A. (2008). Adsorption of cooper from aqueous solution by elais guinensis kernel activated carbon. Journal of Engineering Science and Technology, 3(2), 180189.

Vasu, A. E. (2008). Surface modification of activated carbon for enhancement of niekel(II) adsorption E-Journal of Chemistry, 5(4), 814-819.

Wirawan, T. \& Lestari, S. (2008). Pemanfaatan arang hayati aktif tempurung jarak pagar (jatropha curcas l) sebagai adsorben timbal (Pb) dan tembaga (Cu). Jurnal Ilmiah Mahakam(7), 59-67.

Wong, W. W., Abbas, F. M. A., Liong, M. T. \& Azhar, M. E. (2008). Modification of durian rind pectin for improving biosorbent ability, International Food Research Journal, 15(3), 363365. 